\title{
Employee Retention: A Review of Literature
}

\author{
Bidisha Lahkar Das ${ }^{1}$, Dr. Mukulesh Baruah ${ }^{2}$ \\ ${ }^{I}$ (Research Scholar, KKHSOU Guwahati, Assam, India.) \\ ${ }^{2}$ (Principal, GIMT, Guwahati, Assam, India)
}

\begin{abstract}
Human resources are the life-blood of any organization. Even though most of the organizations are now a days, found to be technology driven, yet human resources are required to run the technology. They are the most vital and dynamic resources of any organization. With all round development in each and every area of the economy, there is stiff competition in the market. With this development and competition, there are lots and lots of avenues and opportunities available in the hands of the human resources. The biggest challenge that organizations are facing today is not only managing these resources but also retaining them. Securing and retaining skilled employees plays an important role for any organization, because employees' knowledge and skills are central to companies' ability to be economically competitive. Besides, continuously satisfying the employees is another challenge that the employers are facing today. Keeping into account the importance and sensitivity of the issue of retention to any organization, the present study tries to review the various available literature and research work on employee retention and the factors affecting employee retention and job satisfaction among the employees.
\end{abstract}

Keywords: Human resources, employee retention, job satisfaction, literature.

\section{Introduction}

Long-term health and success of any organization depends upon the retention of key employees. To a great extent customer satisfaction, organizational performance in terms of increased sales, satisfied colleagues and reporting staff, effective succession planning etc., is dependent upon the ability to retain the best employees in any organization. Encouraging employees to remain in the organization for a long period of time can be termed as employee retention. It is a process in which the employees are encouraged to remain with the organization for the maximum period of time or until the completion of the project. Maertz \& Campion (1998)[1] stated "relatively less turnover research has focused specifically on how an employee decides to remain with an organization and what determines this attachment... retention processes should be studied along with quitting processes". Zineldin, (2000) [2] has viewed retention as "an obligation to continue to do business or exchange with a particular company on an ongoing basis". Denton (2000) [3] has clearly stated that employees who are happy and satisfied with their jobs are more dedicated towards their work and always put their effort to improve their organizational customer's satisfaction. Stauss et al., (2001)[4] has defined retention as "customer liking, identification, commitment, trust, readiness to recommend, and repurchase intentions, with the first four being emotional-cognitive retention constructs, and the last two being behavioral intentions" . Panoch, (2001)[5] forwarded the view that organizations today take great care in retaining its valuable employees and good employees as they are increasingly becoming more difficult to find . Walker (2001) [6] was of the view that managing and retaining promising employees' is an important fundamental mean of achieving competitive advantage among the organizations. Cutler (2001) [7] was of the view that one of the most important demands on management today in any organization is keeping the most vital and dynamic human resources motivated and dedicated. It is not important to see who the organization hires but what counts is that who are kept in the firm. Steel, Griffeth, \& Hom (2002) [8] added to this view that "the fact is often overlooked, but the reasons people stay are not always the same as the reasons people leave". Researchers such as Amadasu( 2003) [9]; Taplin et al.(2003) [10]; Gberevbie(2008) [11] have found that if appropriate employee retention strategies are adopted and implemented by organisations employees will surely remain and work for the successful achievement of organisational goals . In the view of Acton et al., (2003) [12], the Human Resource Department plays an active role in retaining its employees. It make policies for employee betterment such that employee would be satisfied with the organization and stay with the firm for longer time. This shows that it is not just retention of employees but also retention of valued skills. This shows that it is not just retention of employees but also retention of valued skills. Resrarchers such as Cascio(2003) [13];Heneman and Judge(2003) [14]; Gberevbie (2008) have agreed that an organization's inability to formulate and implement strategies capable of recruiting competent employees and retaining them to achieve organizational goals is one of the main challenge facing organizations in the area of performance. Workforce Planning for Wisconsin State Government (2005) [15] has defined employee retention as ".... systematic effort to create and foster an environment that encourages employees to remain employed by having policies and practices in place that 
address their diverse needs." According to Olowu and Adamolekun (2005) [16], it is becoming more essential to secure and manage competent human resource as the most valuable resource of any organization, because of the need for effective and efficient delivery of goods and services by organizations, whether in public or perivate sector. Therefore, for an organization to realize its goals, appropriate strategies for employee recruitment and retention are sine-qua-non for enhanced performance. Researcher such as Kaliprasad (2006) [17] has confirmed that despite the fact that a company may try to bring all these factors into play to enhance employee retention, an employee can still choose to leave the workplace because of, for example, bad management. Kaliprasad (2006) pointed out that an organizations ability to retain its employees completely depends upon its ability to manage them. He found out four interlinked processes that can be utilized for an effective human resource management system: the motivational process; the interaction process; the visioning process; and the learning process. Baker (2006) [18] gave stress on the fact that hiring new employees are far difficult as well as costlier than to keep the current employees in the organization. That is why the core issue in any organization is to give a continuous ongoing effort to identify and try to keep all the best performers irrespective of their age. Gberevbie (2008) has stated that employee retention strategies refer to the plans and means, and a set of decision-making behavior put formulated by the organizations to retain their competent workforce for performance.

\section{Objectives of the study}

This study on review of literature on retention initiatives undertakes the following objectives:

I. To find out the various research works that have been done in the area of employee retention.

II. To highlight the various factors which affect retention initiatives in an organization.

III. To explore the relation between various factors and job satisfaction.

\section{Methodology}

The study is descriptive in nature and only secondary data has been used in it. The secondary data consist of the books and various research journals.

\section{Factors affecting Employee Retention}

Fitz-enz (1990) [19] recognized that employee retention is not influenced by a single factor, but there are hosts of factors which are responsible for retaining employees in an organization. Management need to pay attention to factors such as compensation \& rewards, job security, training \& developments, supervisor support culture, work environment and organization justice etc. According to Osteraker (1999) [20], the employee satisfaction and retention are the key factors for the success of an organization. The Retention factor can be divided into three broad dimensions, i.e., social, mental and physical. The mental dimension of retention consist of work characteristics, employees always prefer flexible work tasks where they can use their knowledge and see the results of their efforts which, in turn, helps in retaining the valuable resources. The social dimension consists of the contacts that the employees have with other people, both internal and external. The physical dimension consists of working conditions and pay. Stein (2000) [21], Clarke (2001) [22], Parker and Wright (2001) [23] have rightly observed that organization must utilize an extensive range of human resource management factors to influence employee commitment and retention. Walker (2001) identified seven factors that can enhance employee retention: (i) compensation and appreciation of the performed work, (ii) provision of challenging work, (iii) chances to be promoted and to learn, (iv) invitational atmosphere within the organization, (v) positive relations with colleagues, (vi) a healthy balance between the professional and personal life, and (viii) good communications. Together, these suggest a set of workplace norms and practices that might be taken as inviting employee engagement. Kehr (2004) [24] divided the retention factors into three variables: power, achievement and affiliation. Dominance and social control represents power. When personal performance exceeds the set standards, it represents achievement and affiliation refers to social relationships which are established and intensified. Hytter (2007) [25] found that factors such as personal premises of loyalty, trust, commitment, and identification and attachment with the organization have a direct influence on employee retention. She also explained that workplace factors such as rewards, leadership style, career opportunities, the training and development of skills, physical working conditions, and the balance between professional and personal life have an indirect influence. Pritchard (2007) [26] was of the opinion that training and development is one of the important retention programmes incorporated in an effort to retain their employees. Eva Kyndt , Filip Dochy et al.,(2009) [27] have found in their study, while investigating employee retention that personal factors such as level of education, seniority, self-perceived leadership skills, and learning attitude and organizational factors such as appreciation and stimulation, and pressure of work are of great relevance in employee retention. Table 1 below shows the various factors of employee retention and the associated research papers along with the contributing authors. 
Table 1: Factors, Contributing authors and Research papers

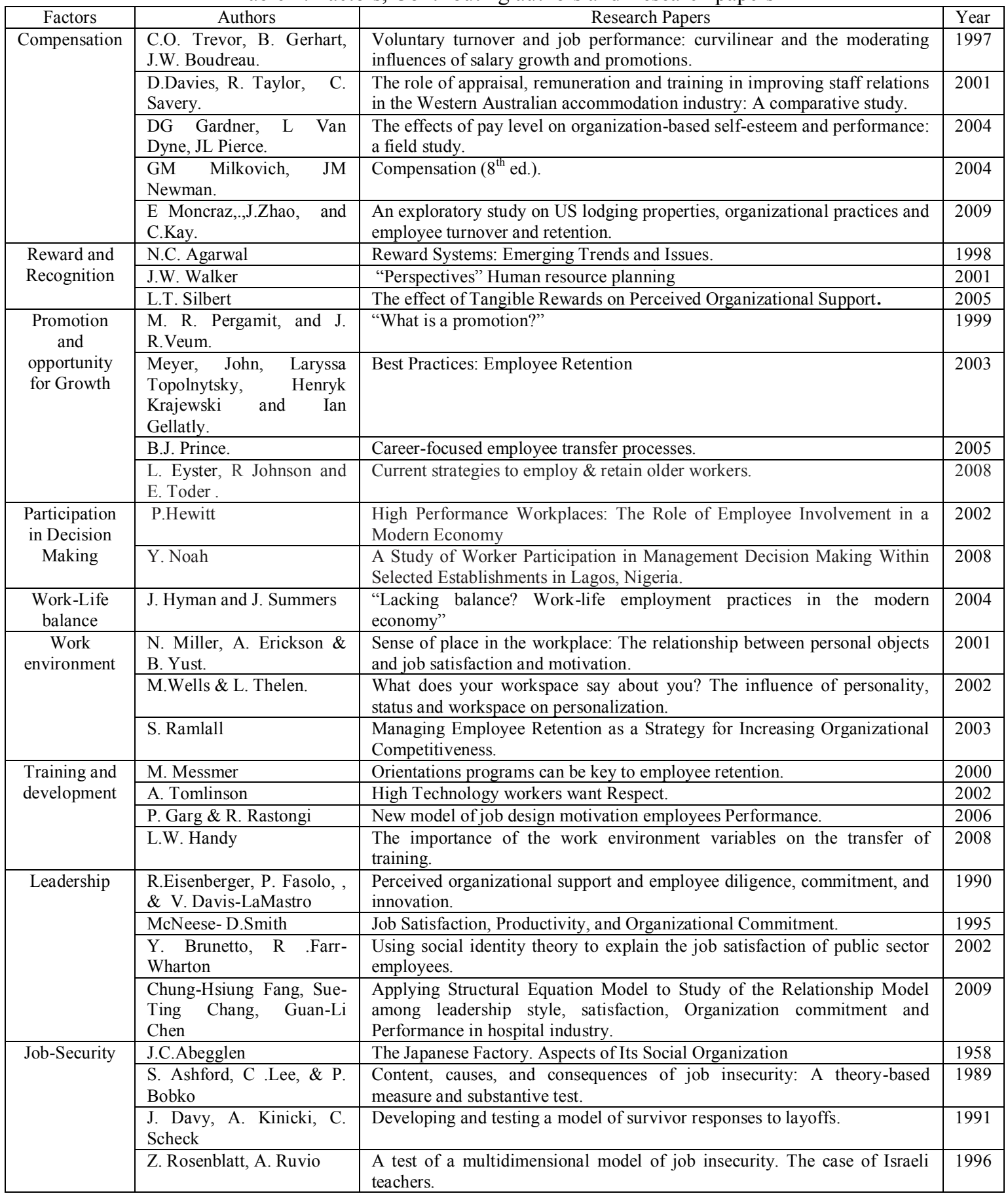

\subsection{Compensation and employee retention}

Trevor et al. (1997) [28] has proved that rise in pay has a negative impact on turnover. Davies, Taylor, \& Savery (2001) [39] forwarded the view that compensation to top workers is given by every organization but very few organizations uses it strategically. They said that "Salary and benefits policies are not being used strategically, within the organization to improve morale, reduce turnover, and achieve targets within an establishment". Gardner et al., (2004) [30] were of the view that pay is considered as a motivator as well as employee retention technique. Milkovich and Newman (2004) [31] have clearly stated that among all types of reward, monetary pay is considered one of the most important and significant factor in retention. In a research by Moncraz, Zhao and Kay (2009) [32] it was concluded that although compensation was not one of the top factors influencing non-management turnover but compensation can act as a critical factor in reducing managerial turnover and increasing commitment 


\subsection{Reward and recognition}

Agarwal (1998) [33] gave an explanation to the term reward as something that the organization offers to the employees in response of the work as well as performance and something which is desired by the employees. According to Walker (2001), recognition from bosses, team members, coworkers and customer enhance loyalty. "Watson Wyatt" a global consulting firm, conducted a survey in USA, in the year 2002 [34] among 12750 employees at all levels of job and in all major industry sectors to know about their attitudes toward their workplace and their employers. It was found in the survey that recognition is important for workers and they want to listen that their work followed recognized and appreciated. Silbert (2005) [35] forwarded the view that reward is important because it has an enduring impression on employees which, in turn, gives the employees an impression that they are valued in the organization.

\subsection{Promotion and Opportunity for growth}

Pergamit and Veum (1989) [36] in their study found a close and positive correlation between promotions and job satisfaction and which in turn helps in retaining employees. Research by Meyer et al, (2003) [37] has shown internal career development of employees is often the best predictor of an employee's effective commitment. Prince (2005) [38] argued that talented employees are required for maintaining a competitive advantage and employees want career growth opportunities to develop and rise in their career ladder. Such plans include advancement plans, internal promotion and accurate career previews at the time of hiring. Eyster, et al. (2008) [39] state that job flexibility along with lucrative career and life options, is a critical incentive for all employees.

\subsection{Participation in decision-making}

Hewitt (2002) [40] has mentioned that modern businesses always keeps its employees well informed about all the important affairs of its business and involves them in decision-making at all levels which can exploit the talents of its employees. Supporting the view Noah (2008) [41] found in his research that employee involvement in decision-making helps in creating a sense of belongingness among the employees, which helps in creating a good congenial working environment and contributes towards building a good employer-employee relationship.

\subsection{Work-life balance and employee retention}

Work-life balance is increasingly important for engagement and affects retention. Hyman et al., (2003) [42] in their empirical research in the UK found that interventions of work demands into personal life (e.g. working during the week-end) resulted into heightened stress and emotional exhaustion among the employees. In a study conducted by the Australian Telework Advisory Committee (2006) [43] it was found that $70 \%$ of businesses that incorporated telework options reported a number of positive benefits, such as increased business productivity and reduced costs, improved employee flexibility and work life balance, and increased workforce participation .

\subsection{Work environment and employee retention}

According to Miller, Erickson \& Yust (2001) [44], employees get benefited by work environment that provide sense of belonging. Wells \& Thelen (2002) [45] have stated in their study that organizations which have generous human resource policies, have a very good chance to satisfy and retain employees by providing them an appropriate level of privacy and sound control on work environment which enhances the motivation levels to commit with the organization for the long term. Ramlall (2003) [46] stressed the need for recognizing the individual needs of an employee in an organization as it will encourage commitment and provide a suitable work environment.

\subsection{Training and Development and Employee Retention}

Messmer (2000) [47] found that one of the important factors in employee retention is investment on employee training and career development. Organization always invests in the form of training and development on those workers from whom they expect to return and give output on its investment. Tomlinson (2002) [48] forwarded the view that organizations can keep the leading edge in this competitive world by having their employees well trained in the latest technologies. Garg \& Rastogi (2006) [49], explained that in today's competitive environment feedback is very essential for organizations from employees and the more knowledge the employee learn, the more he or she will perform and meet the global challenges of the market place. Handy (2008) [50] has mentioned that proper innovation, and assimilation of new knowledge is essential for survival in any work environment. Thus knowledge is the most expensive asset of any firm. 


\subsection{Leadership and Employee Retention}

Eisenberger and associates (1990) [51] suggested that employee's perception regarding an organization is strongly influenced by their relationship with the supervisor. McNeese-Smith (1995) [52] mentioned in his study on Leadership behavior of hospital directors found that there is significantly positive relation between productivity, work satisfaction and organizational commitment of staff. Brunetto and Farr-Wharton (2002) [53] were of the view that supervision of the immediate manager increases the level of job satisfaction in the public sector employees. Chung-Hsiung Fang, Sue-Ting Chang, Guan-Li Chen (2009) [54] has found that leadership style can affect organizational commitment and work satisfaction positively and work satisfaction can affect organizational commitment and work performance positively.

\subsection{Job Security and Employee Retention}

Abegglen (1958) [55] found during the study of Japanese workers that employment features like lifetime employment and seniority system, job security lead to high commitment, job satisfaction as well as retention of employees in an organization .Researchers such as Ashford et al., (1989) [56]; Davy et al., (1991) [57] conducted studies on job security and job satisfaction and found that that job dissatisfaction is the outcome of insecurity among employees. Rosenblatt and Ruvio, (1996) [58] conducted a research on the job insecurity and found that job performance and organizational commitment are negatively correlated with job insecurity.

\section{Job satisfaction}

Hoppock (1935) [59] was of the view that job satisfaction is any combination of psychological, physiological and environmental circumstances, which cause a person truthfully, satisfied with his/her job.

Locke (1976) [60] defined job satisfaction as" a pleasurable or positive emotional state resulting from the appraisal of one's job or job experience."

Feldman and Arnold (1983) [61] have defined job satisfaction as," Job satisfaction will be defined as the amount of overall positive affect (or feelings) that individuals have towards thir jobs".

Davis et al., (1985) [62] stated that job satisfaction is a combination of positive and negative feelings that workers have towards their work. When a worker joins a business organization, he brings with him the needs, desires and experiences which he expects from his job. Job satisfaction represents the extent to which expectations matches with the real awards. Job satisfaction is closely linked to that individual's behavior in the work place.

Researchers such as Ashford et al., (1989) [63]; Davy et al., (1991) [64] found in their studies that insecurity among employees leads job dissatisfaction.

Rain, Lane \& Steiner (1991) [65] states that job satisfaction is correlated to life satisfaction which means that people who are satisfied with life will tend to be satisfied with the job and people who satisfied with job will tend to satisfied with their life.

Lane et al.,(2010) [66] and Vidal at al.,(2007) [67] in their researches/studies found that job satisfaction is a complex phenomenon which is influenced by factors like salary, working environment, autonomy, communication and organizational commitment.

According to Reichheld (1996) [68] there are three criteria that have impact upon how hard employees are working. They work hard when: (1) they have job pride, (2) when they find their jobs interesting and meaningful, and (3) when they are recognized for their work and benefit from the work they have accomplished. A relevant research by Spector (1997) [69] and Hirschfeld (2000) [70] indicate that the different aspects of job satisfaction could be split according to Herzberg's two dimensions. The intrinsic satisfaction refers to job tasks and job content such as variety, autonomy, skill utilization, self-fulfillment and self-growth.

Murray (1999) [71] has clearly stated that job satisfaction has direct effect on level of absenteeism, commitment, performance and productivity. Furthermore, job satisfaction not only improves the retention of employees but also reduces the cost of hiring new employees.

Sokoya (2000) [72] in his investigation on job satisfaction level among the public sector managers found that income or compensation is the most valuable determinant of job satisfaction. In a study by $\mathrm{Al}-$ Aameri, (2000) [73] it was found that satisfied employees tend to be more productive, creative, and committed to their employers, and recent studies have shown a direct correlation between staff satisfaction and patient satisfaction in health care organizations.

\section{Employee Turnover}

Many researchers have tried to answer the question as to what determines people's intention to quit by investigating possible antecedents of employees' intentions to quit. Until date, there has been little consistency in findings, which is partly due to the diversity of employed included by the researchers and the lack of consistency in their findings. Therefore, there are several reasons why people quit from one organization to another or why people leave organization. 
Chruden (1980) [74], Testa (2008) [75] in their studies have found that high turnover rates of skilled professionals can pose as a risk to the business or organization, due to human capital (such a skills, training and knowledge) cost. Notably, given the natural specialization of skilled professionals, these employees are likely to be reemployed within the same industry by a competitor.

Price \& Muller (1981)[76] in their study on 1091 registered nurses in seven hospitals found that job dissatisfaction influenced actual turnover indirectly through its direct effect on turnover intention.

Costly et al. (1987) found that the main causes of high labour turnover in an organization are poor personnel policies, poor recruitment policies, poor supervisory practices, poor grievance procedures, or lack of motivation. All these factors indicate that there is no proper management practices and policies on personnel matters hence the employees are not recruited scientifically, promotion policy of the organization is not communicated to the employees properly, no grievance procedures are there in the organization and as such the employees decides to quit.

Zedeck and Mosier, (1990) [77] has mentioned that the issue of employee turnover is very crucial and important to managers, researchers and individuals.

Jackson, (1981) [78] and Stear (1991) [79] have stated in their studies that high turnover is caused by unhappiness with the work, inadequate compensation, unsafe and unhealthy conditions, unrealistic expectations, inappropriate processes or tools, and poor candidate screening. Other causes are lack of career opportunities and challenges, dissatisfaction with the job-scope or conflict with management.

From the point of view of Susskind at el., (2000) [80] turnover problem should be dealt with careful strategies exclusively concentrating on human resource problems.

Zuber, (2001) [81] found that employees are more likely to stay when there is a predictable work environment and vice versa. Zuber also stated that instable organization have a high degree of employee turnover.

Kevin et al. (2004) [82] have stated that although, there is no standard framework for understanding the employees turnover process but a wide range of factors are useful in predicting employee turnover.

Henry Ongori (2007)[83] concluded in his study that employees are the long-term investments in an organization and as such management should encourage job redesign, task autonomy, task significance and task identity, open book management, empowerment of employees, recruitment and selection must be done scientifically with the objective of retaining employees and decreasing employee turnover.

\section{Employee retention, employee satisfaction and employee turnover model}

A major challenge faced by the employees today is retaining the hired employees in its organization. In the age of cut throat competition every organization tries its level best to give the best facilities to its employees. Satisfying the human sources is one of the toughest tasks which majority of the organizations faces today. Understanding and knowing what is going on in the human mind is very difficult to understand. Besides there are so many opportunities available for the skilled as well as talented human resources that it is becoming very tough as well as difficult for the employers to satisfy and retain them. There is no single strategy or retention plan which may satisfy each and every employee in an organization. As we have different personalities as such we have different demands and expectations from the organization. Many researchers such as Arnold and Feldman, (1982) [84]; Wotruba and Tyagi, (1991) [85]; Brodie, (1995) [86] have found and concluded in their study that age, job satisfaction, tenure, job image, met expectations, organizational commitment are consistently related to turnover intentions and the actual turnover. Research findings by Jewell and Segall, (1990) [87] and Locke (1976) [88] have clearly stated that people, who are satisfied with their jobs, tend to stay in them longer, i.e. lower turnover, and be less absent. Researchers such as Carsten and Spector (1987) [89] conducted a metaanalysis to find the relationship between job satisfaction and turnover and found a negative correlation between both the variables. Harrington et al. (2001) [90] examined the various predictors of intentions to leave a job and observed that emotional exhaustion; lower levels of intrinsic job satisfaction and dissatisfaction with salary and promotional opportunities were the main predictors. Gurpreet Randhawa (2007) [91] concluded in her study that a significant correlation between job satisfaction and turnover intentions suggesting thereby that higher the job satisfaction, lower is the individual's intention to quit the job. 


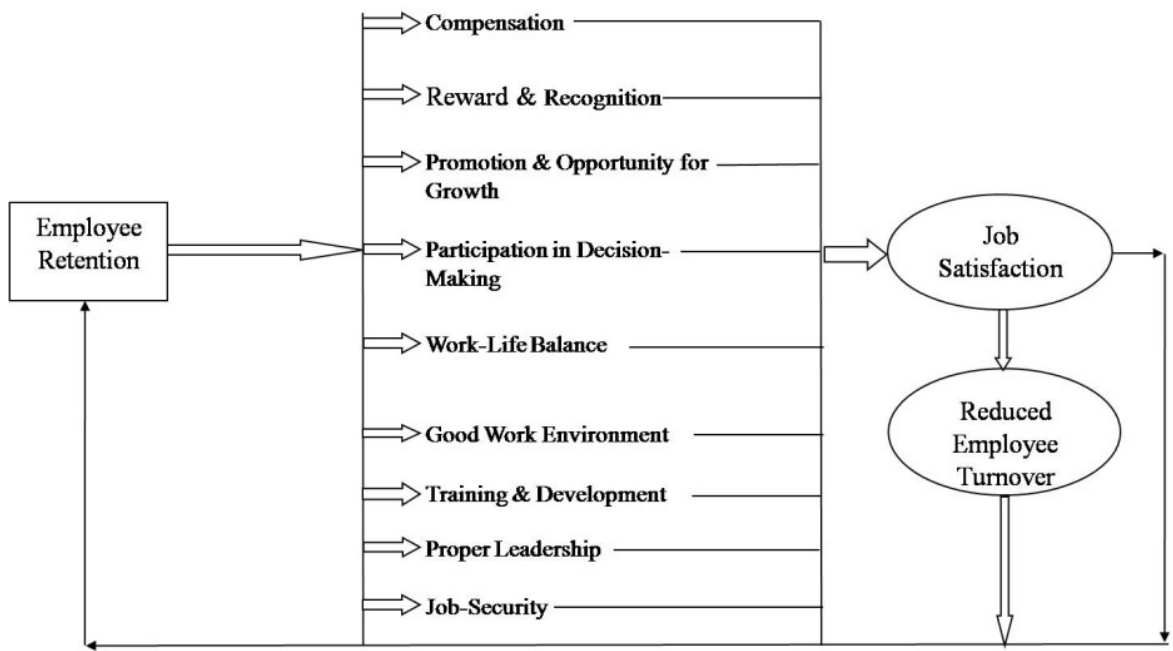

Figure 1: The Employee Retention \& Job Satisfaction Model

The above model clearly depicts that employee retention factors have a direct relationship with job satisfaction. If these factors exist in the organization then the tendency to leave the job or switch over to some other job gets reduced. Thus job satisfaction as well as employee turnover are always negatively correlated to one another. The model clearly shows that if the above mentioned factors exist in the organization it will not only help to attract new employees into the organization but will also lead to the retention of the existing employees into the organization. Lee and Mowday (1987) [92] and Tett and Meyer (1993)[93] in their studies have concluded that high job satisfaction leads to lower turnover, while low satisfaction leads to higher turnover.

\section{Conclusion}

Human resources are complex and not easy to understand. These are the assets which can make as well as break an organization. Retaining them will help in the long-term growth of an organization and will also add to their goodwill. But the most difficult task faced by an organization today is retaining as well as satisfying these resources. Although the research paper tried its level best to reveal the various research works done and the contributions forwarded by various researchers in the area of employee retention and job satisfaction, but still much scope remains for more exploration in the field of employee retention and it by taking into consideration the factors like compensation practices, leadership and supervision, career planning and development, alternative work schedule, working conditions, flexible working hours etc. Needless to say that these efforts should be conducted by HR professionals.

\section{Journals}

\section{References}

[1]. Maertz, C.P., Jr., \& Campion, M.A. (1998). 25 years of voluntary turnover research: A review and critique. International Review of Industrial and Organizational Psychology, 13, 49- 81.

[2]. Denton, J. (2000), "Using Web-based projects in a systems design and development course". Journal of Computer Information Systems, Vol. 40 No.3, pp.85-7

[3]. Stauss, B., Chojnacki, K., Decker, A., Hoffman, F. (2001). "Retention effects of a customer club", International Journal of Service Industry Management, Vol. 12 No.1, pp.7-19.

[4]. Cutler, G. (2001). Internet summons Pete to jump ship. Research Technology Management

[5]. Steel, R.P., Griffeth, R.W., \& Hom, P.W. (2002). Practical retention policy for the practical manager. Academy of Management Executive, 16, 149-162.

[6]. Amadasu, D.E. (2003). "Personnel and the Nigerian Management Crisis: Ajaokuta Iron and Steel Mill Examined." Abuja Management. Rev. 1:4

[7]. Taplin, I.M., Winterton, J.,Winterton, R.,2003.”Understanding Labour Turnover in a Labour Intensive Industry: Evidence from British Clothing Industry." Journal of Manage. Stud. 40:4.

[8]. Acton, T., Golden, W.(2003). "Traning the knowledge worker: A descriptive study of training practices in Irish software companies". Journal. Eur.Ind. Train, 27(4):137-146.

[9]. Kaliprasad, M. (2006). The human factor I: attracting, retaining, and motivating capable people. Cost Engineering, 48(6), 20-26.

[10]. Fitz-enz, J. (1990).Getting and keeping good employees. In personnel. 67(8): 25-29.

[11]. Osteraker, M.C. (1999). Measuring motivation in a learning organization. Journal of Work Place Learning.

[12]. Stein, N. (2000). Winning the war to keep top talent: yes you can make your workplace invincible. In fortune. 141(11):132-38

[13]. Clarke, K.F. (2001). What businesses are doing to attract and retain employee- becoming an employer of choice. In Employee Benefits Journal.pp. 34-37.

[14]. Parker, O. and Wright, L. (2001). Pay and employee commitment: the missing link. In Ivey Business Journal.65 (3): 70 -79.

[15]. Kehr, H. M. (2004). Integrating implicit motives, explicit motives, and perceived abilities. The compensatory model of work motivation and volition. Academy of management review. 
[16]. Hytter, A. (2007). Retention strategies in France and Sweden. The Irish Journal of Management, 28(1), 59-79..

[17]. Kyndt Eva, Dochy Filip ,Michielsen Maya, Moeyaert Bastiaan (2009). Employee Retention: Organisational and Personal Perspectives, Vocations and Learning DOI 10.10.07/s12186-009-9024-7.

[18]. Trevor CO, Gerhart B, Boudreau JW (1997). Voluntary turnover and job performance: curvilinear and the moderating influences of salary growth and promotions. Journal of Applied. Psychology., 82(1): 44-61.

[19]. Davies, D., Taylor,R., Savery, C (2001). "The role of appraisal, remuneration and training in improving staff relations in the Western Australian accommodation industry: A comparative study". Journal of European Training, 25 (6/7). 366-373.

[20]. Gardner DG, Van Dyne L, Pierce JL (2004). The effects of pay level on organization-based self-esteem and performance: a field study. Journal of Occup. Organ. Psychology., 77(3): 307-322.

[21]. Moncraz, E., Zhao, J., and Kay, C. (2009). An exploratory study on US lodging properties', organizational practices and employee turnover and retention. International Journal of Contemporary Hospitality Management, 21 (4). 437-458.

[22]. Agarwal, N.C. (1998). "Reward Systems: Emerging Trends and Issues". CanadianPsychology, 39(1), 60-70.

[23]. Silbert, L.T. (2005). The effect of Tangible Rewards on Perceived Organizational Support. Management Sciences.

[24]. Pergamit, M. R. and Veum, J. R. (1999), "What is a promotion?" Industrial and Labor Relations Review, Vol. 52 No. 4, pp. 581 601.

[25]. Prince, B.J. (2005). Career-focused employee transfer processes. Career Development International, 10(4), 293-309.

[26]. Eyster, L., Johnson, R. and Toder, E. (2008). "Current strategies to employ \& retain older workers". [PDFdocument]. Retrieved from: http://www.urban.orguploadedPDF/411626_0lderworkers.pdf.

[27]. Hewitt, P. (2002). High Performance Workplaces: The Role of Employee Involvement in a Modern Economy. www.berr.gov.uk/files/file26555.pdf

[28]. Noah, Y. (2008) A Study of Worker Participation in Management Decision Making Within Selected Establishments in Lagos, Nigeria. Journal of Social Science, 17 (1): 31-39.

[29]. Hyman, J. and Summers, J. (2004), "Lacking balance? Work-life employment practices in the modern economy", Personnel Review, Vol. 33, pp. 418-29.

[30]. Miller, N., Erickson, A., \& Yust, B. (2001). "Sense of place in the workplace: The relationship between personal objects and job satisfaction and motivation." Journal of Interior Design, 27(1), 35-44

[31]. Wells, M., \& Thelen, L. (2002) "What does your workspace say about you? The influence of personality, status and workspace on personalization." Environment and Behavior, 3: 300-321.

[32]. Ramlall, S. (2003). Managing Employee Retention as a Strategy for Increasing Organizational Competitiveness, Applied H.R.M. Research, 8(2), 63-72.

[33]. Messmer, M. (2000). Orientations programs can be key to employee retention. In Strategic Finance. 81 (8):12-15.

[34]. Tomlinson, A. (2002). High Technology workers want Respect. Survey Canadian Human Resources Reporter, vol. 15, issue 3, and p.2.

[35]. Garg, P. \& Rastongi, R. (2006). New model of job design motivation employees Performance. Journal of Management Development.

[36]. Eisenberger, R., Fasolo, P., \& Davis-LaMastro, V. (1990). "Percieved organizational support and employee diligence, commitment, and innovation". Journal of Applied Psychology, 75, 51-59.

[37]. McNeese-Smith D., “Job Satisfaction, Productivity, and Organizational Commitment”. Journal of Nurse Association, $25(9), 1995$. $17-26$

[38]. Brunetto Y, Farr-Wharton R (2002). "Using social identity theory to explain the job satisfaction of public sector employees". International Journal of Public Sector Manage, 15 (7): 534-551.

[39]. Chung-Hsiung Fang, Sue-Ting Chang, Guan-Li Chen (2009) "Applying Structural Equation Model to Study of the Relationship Model among leadership style, satisfaction, Organization commitment and Performance in hospital industry".

[40]. Ashford, S, Lee,C \& Bobko, P. (1989). "Content, causes, and consequences of job insecurity: A theory-based measure and substantive test", Academy of Management Journal., 32: 803-829

[41]. Davy J, Kinicki A, Scheck C (1991). Developing and testing a model ofsurvivor responses to layoffs. Journal of Vocational Behaviour. 38: 302-317

[42]. Rosenblatt Z, Ruvio A (1996). A test of a multidimensional model of job insecurity. The case of Israeli teachers. Journal of Organisational Behaviour., 17: 587- 605.

[43]. Ashford, S, Lee, C\&Bobko, P. (1989). Content, causes, and consequences of job insecurity: A theory-based measure and substantive test. Academy of Management. Journal., 32: 803-829

[44]. Davy J, Kinicki A, Scheck C (1991). Developing and testing a model of survivor responses to layoffs. Journal of Vocational Behaviour, 38: 302-317.

[45]. Lane, K.A., Esser, J., Holte, B., McCusker, M.A., (2010). A study of nurse faculty job satisfaction in commnity colleges in Florida. Teach. Learn.Nurs., 5:16-26.

[46]. Vidal, M.E.S., Valle, R.S., Aragon, B.M.I.,2007.Antecedents of repatriates' job satisfaction and its influence on turnover intentions: Evidence from Spanish repatriated managers. Journal of Bus.Res.,60: 1272-1281.

[47]. Reichheld, FF (1996). The loyalty effect: The hidden force behind growth, profits, and lasting value. Bain \& Company, Inc, Boston

[48]. Hirschfeld, R.R., 2000. Does revising the intrinsic and extrinsic subscales of the Minnesota Satisfaction Questionnaire Short Form make a difference. Educ. Psychol. Measure., 60: 255-270. DOI: 10.11.77/00131640021970493

[49]. Murray R A (1999). Job Satisfaction of Professional and Paraprofessional Library Staff at Chapel Hill, North Carolina. University of North Carolina at Chapel Hill.

[50]. Sokoya, S K (2000). Personal Predictors of Job Satisfaction for the Public Sector Manager. Implications for Management Practice and Development in a Developing Economy.Journal of Business in Developing Nations.

[51]. Al-Aameri, A. S., (2000).” Job satisfaction and organizational commitment for nurses.” Saudi Medical Journal, 21(6), 231-235.

[52]. Price, J. \& Muller, C. (1981). A casual model of turnover of nurses. Academy of Management Journal, 24(3), 543-565.

[53]. Susskind, A.M.,Borchgrevink, C.P.,Kacmar,M.K., Brymer, R.A., (2000).Customer Service Employees' Behavioural Intentions and Attitude: An examination of Construct Validity and a Path Model. International Journal of Hospitality Management, 19(1), 53-77.

[54]. Zuber A (2001). "A career in food service cons: high turnover", Nations Restaurant News, 35 (21):147-148.

[55]. Kevin MM, Joan LC, Adrian JW (2004). “Organizational change and employee turnover” Personnel Rev. 33 (2):161-166.

[56]. Ongori Henry(2007) A review of the literature on employee turnover. African Journal of Business Management, pp. 049-054, June 2007.

[57]. Arnold, H. J.; and Feldman, D. C. (1982), "A Multivariate Analysis of the Determinants of Job Turnover", Journal of Applied Psychology, Vol. 67, pp. 350-360 
[58]. Wotruba, T. R.; and Tyagi, P. K. (1991). "Met Expectations and Turnover in Direct Selling", Journal of Marketing, Vol. 55, pp. 2425 .

[59]. Carsten, J. M.; and Spector, P. E. (1987). "Unemployment, Job Satisfaction, and Employee Turnover: A Meta-Analytic Test of the Muchinsky Model". Journal of Applied Psychology, Vol. 72, pp. 374-381.

[60]. Harrington, D.; Bean, N.; Pintello, D.; and Mathews, D.(2001), "Job Satisfaction and Burnout: Predictors of Intentions to Leave a Job in a Military Setting", Administration in Social Work, Vol. 25, No.3, pp. 1-16.

[61]. Randhawa Gurpreet (2007).Relationship between Job Satisfaction and Turnover Intentions : An Empirical Analysis, Indian Management Studies Journal 11

[62]. Lee, T. W.; and Mowday, R. T. (1987). "Voluntarily Leaving an Organization: An Empirical Investigation of Stress and Mowdays Model of Turnover", Academy of Management Journal, pp. 721-743.

[63]. Tett, R. P.; and Meyer, J. P. (1993). "Job Satisfaction, Organizational Commitment, Turnover Intention and Turnover: Path Analysis based on Meta Analytic Findings", Personnel Psychology, Vol. 45, pp. 259-293.

\section{Theses}

[64]. Panoch, A. (2001 May). The Relationship Between Diversity and Employee Retention . Master's Thesis, University of WisconsinStout, Menomonie

[65]. Gberevbie DE.2008. Staff Recruitment, Retention Strategies and Performance of Selected public and Private organizations in Nigeria. Ph.D. Thesis.Coll.Bus.Soc.Sci.,Covenant Uni., Ota.

[66]. Handy, L.W. (2008). The importance of the work environment variables on the transfer of training. Unpublished PhD Thesis, Department of Education ,University of North Carolina State University, Carolina, USA.

[67]. Brodie, A. S. (1995). Salesforce Turnover in Direct Selling Organizations in the United Kingdom and France. Master's Thesis, Books Keele University

[68]. Zineldin, M. (2000).TRM Total Relationship Management, Student litterateur, Lund.

[69]. Walker, J.W. (2001). "Perspectives" Human resource planning.24 (1):6-10.

[70]. Cascio, W.F., (2003).Managing Human Resources: Productivity, Quality of Work Life, and Profits. (6 ${ }^{\text {th }}$ Edition).Boston: McGrawHill, Irwin.

[71]. Heneman, H.G., Judge, T.A., (2003). Staffing Organization (4 ${ }^{\text {th }}$ Edition). Boston McGraw-Hill, Irwin.

[72]. Olowu, D.,Adamolekun, L.,(2005).Human Resource Management. In L.Adamolekun (ed) Public Administration in Africa: Main Issues and Selected Country Studies. Ibadan: Sprectrum Books.

[73]. Baker, E. (2006). The human factor. CIO Insight, 73, 40-50.

[74]. Pritchard CW (2007). 101 Strategies for recruiting success: where, when, and how to find the right people every time. New York: AMACOM.

[75]. Milkovich GM, Newman JM (2004). Compensation (8th ed.). Burr Ridge, IL: Irwin McGraw-Hill.

[76]. Meyer, John, Laryssa Topolnytsky, Henryk Krajewski and Ian Gellatly (2003). Best Practices: Employee Retention. Toronto: Tomson-Carswell.

[77]. Wells, M., \& Thelen, L. (2002) What does your workspace say about you? The influence of personality, status and workspace on personalization. Environment and Behavior, 3: 300-321.

[78]. Abegglen, J.C (1958). The Japanese Factory. Aspects of Its Social Organization. Free Press. Glencoe. IL.

[79]. Hoppock, R. (1935). Job Satisfaction, Harper and Brothers, New York, p. 47.

[80]. Feldman, D.C., \& Arnold, H.J., (1983). Managing Industrial and Group Behaviour in Organizations McGraw-Hill, New York, p. 192.

[81]. Davis, K. and Nestrom, J.W. (1985). Human Behaviour at work: Organizational Behaviour. $7^{\text {th }}$ Edition, McGraw Hill, New York, p.109.

[82]. Rain, JS, Lane, IM \& Steiner, D.D. (1991) .A current look at the job satisfaction/ life satisfaction relationship: Review and future considerations. Human Relations.p. 44, pp. 287-307.

[83]. Spector, P.E., (1997). Job Satisfaction: Application, Assessment, Causes and Consequences (Advanced Topics in Organizational Behavior). 1st Edition, Sage Publications, CA, pp: 104.

[84]. Chruden, S., (1980). Personnel Management. The Utilization of Human Resources. Florida South West Press, U.S.A., pp: 54.

[85]. Testa, B., (2008).Early engagement, long relationships? Workforce Management., 15: 27-31.

[86]. Zedeck, S. and Mosier, K.L. (1990). Work in the family and employing organization. American Psychologist, 45, 240-251

[87]. Jackson, M., (1981). Personnel. 2nd Edition. Heinemann Publishers, London

[88]. Stear, R.M., (1991). Motivation and Work Behaviour. McGraw Hill, U.S.A., pp: 168-266.

[89]. Jewell, L. N.; and Segall, M. (1990). Contemporary Industrial/Organizational Psychology, West Publishing Company, St. Paul.

\section{Chapters in Books}

[90]. Locke, E.A.,(1976) The Nature and Cause of Job Satisfaction, In M. Dunnette(Ed.), Handbook of Industrial and Organizational Psychology(Rand McNally, Chicago) 1976, p.1300.

[91]. Locke, E.A.,(1976) The Nature and Cause of Job Satisfaction, In M. Dunnette(Ed.), Handbook of Industrial and Organizational Psychology( Rand McNally, Chicago, 1976) p.1300.

\section{Reports}

[92]. Workforce Planning for Wisconsin State Government. (2005). Employee retention. Retrieved July 1, 2010.

[93]. Watson, Wyatt. (1999). Work USA 2000: Employee commitment and the bottom line. Bethesda, MD: Watson Wyatt. pp: $43-58$.

[94]. Australian Telework Advisory Committee Report(2006). Telework for Australian Employees and Businesses: Maximising the Economic and Social Benefits of Flexible Working Practices.

[95]. Tomlinson, A. (2002). High Technology workers want Respect, Survey Canadian Human Resources Reporter, vol. 15, issue 3, and p.2. 